\title{
Depression prevalence in Intensive Care Unit nursing workers: a study at hospitals in a northwestern city of São Paulo State
}

\author{
Divane de Vargas ${ }^{1}$ \\ Ana Paula Vieira Dias ${ }^{2}$
}

\begin{abstract}
This study aimed to estimate the prevalence of depression in nursing staff working in Intensive Care Units of hospitals from a city in Northwestern São Paulo State - Brazil, examining its association with participants' socio-demographic characteristics. The Beck Depression Inventory was applied to a sample of 67 nursing workers from three general hospitals, showing an $28.4 \%$ prevalence of depression. The analysis based on the multiple model showed a significant association between depression and marital status $(O R=1.52)$, night work $(O R=1.46)$ and double shifts $(O R=2.11)$. Also, there were significant percentages of workers who reported discouragement, sadness and hopelessness. In conclusion, the prevalence of depression is significant and more attention should be paid to this problem workers at these units face. Further studies are needed in the attempt to broaden knowledge on the subject, which can support strategies to guarantee attention to ICU nursing workers' physical and mental health needs.
\end{abstract}

Descriptors: Depression; Prevalence; Nurse; Nursing; Intensive Care Units.

\footnotetext{
${ }^{1}$ RN, Ph.D. in Nursing, Professor, Escola de Enfermagem, Universidade de São Paulo, Brazil. E-mail: vargas@usp.br.

${ }^{2}$ RN. E-mail: anaenf@hotmail.com.
} 


\title{
Prevalência de depressão em trabalhadores de enfermagem de Unidade de Terapia Intensiva: estudo em hospitais de uma cidade do noroeste do Estado São Paulo
}

Estudo realizado com o objetivo de estimar a prevalência de depressão em trabalhadores de enfermagem de Unidades de Terapia Intensiva (UTI) de hospitais, de uma cidade do noroeste do Estado São Paulo, analisando sua associação às características sociodemográficas dos participantes. Aplicou-se o inventário de depressão de Beck a uma amostra 67 trabalhadores de enfermagem de três hospitais gerais. Observouse prevalência de $28,4 \%$ de depressão. A análise pelo modelo múltiplo demonstrou associação significativa entre depressão e estado civil $(O R=1,52)$, trabalho noturno $(O R=1,46)$ e dupla jornada $(O R=2,11)$. Foram significativos, ainda, os percentuais de trabalhadores que relataram desânimo, tristeza e desesperança. Conclui-se que é significativa a prevalência de depressão e que maior atenção deve ser dada a esse problema enfrentado pelos trabalhadores dessas unidades. Sugere-se a realização de outros estudos na busca por ampliar o conhecimento sobre a temática os quais podem respaldar estratégias que visem assegurar ao trabalhador de enfermagem, das UTIs, atenção a suas necessidades de saúde física e psíquica.

Descritores: Depressão; Prevalência; Enfermeiro; Enfermagem; Unidades de Terapia Intensiva.

\section{Prevalencia de depresión en trabajadores de enfermería de Unidades de Terapia Intensiva: estudio en hospitales de una ciudad del noroeste del Estado de Sao Paulo}

\begin{abstract}
Este estudio fue realizado con el objetivo de estimar la prevalencia de depresión, en trabajadores de enfermería de Unidades de Terapia Intensiva (UTI) de hospitales de una ciudad del Noroeste del estado de Sao Paulo, analizando su asociación con las características sociodemográficas de los participantes. Se aplicó el Inventario de Depresión de Beck a una muestra de 67 trabajadores de enfermería de tres hospitales generales; se observó una prevalencia de $28,4 \%$ de depresión. El análisis por el modelo múltiple demostró asociación significativa entre depresión y estado civil $(O R=1,52)$, trabajo nocturno $(O R=1,46)$ y doble jornada $(O R=2,11)$, fueron significativos también los porcentajes de trabajadores que relataron desanimo, tristeza y desesperanza. Se concluye que es significativa la prevalencia de depresión y que se debe dar mayor atención a ese problema enfrentado por los trabajadores de esas unidades. Se sugiere la realización de otros estudios buscando ampliar el conocimiento sobre la temática, los cuales pueden respaldar estrategias que objetiven asegurar, al trabajador de enfermería de las UTIs, atención a sus necesidades de salud física y psíquica.
\end{abstract}

Descriptores: Depressión; Prevalencia; Enfermeras; Enfermeria; Unidades de Terapia Intensiva.

\section{Introduction}

Literature appoints that correlations exist between task performance and mental illnesses, more precisely depression. The exhaustion people go through in the work environment is one of the most significant factors in the emergence of diseases resulting from stressful stimuli experienced in that environment. Also according to literature ${ }^{(1)}$, health professional are directly affected because they live and work with diseases and the feelings these involve, which constitute an exhausting and stressing process, demanding conscious or unconscious 
defense mechanisms, so that other people's disease and suffering do not interfere in workers' mental and physical health. These mechanisms, however, are not always efficient to cope with these situations and workers may present some changes, mainly mood swings, manifested as depression or irritability.

The term depression has been used to designate a normal affective state (sadness), as well as a symptom, a syndrome and one or several illnesses. In those situations characterized as syndrome, depression presents mood swings (irritability, lack of ability to feel pleasure, apathy), including cognitive, psychomotor and vegetative alterations (sleep and appetite). The main signs and symptoms are characterized by: depressive mood, feeling of sadness, self-devaluation and feeling of guilt; reduced ability to experience pleasure in most part of activities, fatigue or feeling of energy loss; decreased ability to think, concentrate or make decisions. Physiological symptoms tend to take the following forms: sleep alteration, appetite alteration and reduced sexual interest ${ }^{(2)}$.

Studies ${ }^{(3-4)}$ have appointed that the Intensive Care Unit (ICU) is characterized as one of the most aggressive, tense and traumatizing environments in the hospital, which can entail physical and mental health damage for patients as well as the multiprofessional team working there. As a result of increasingly sophisticated, bureaucratized and mechanized Intensive Care Units (ICUs), the environment is very unstable and agitated, with different activities that arouse great anxiety, exposing the nursing team to great tension as, in these environments, besides working with their own emotions and conflicts, these workers also need to deal with their patients and relatives' emotional needs.

These demands often end up causing physical and emotional fatigue, tension and anxiety in professionals. Besides, the context of life risk, work overload, bad use of medical skills, difficulty to accept death, pain, lack of material and human resources, extremely dry and refrigerated environment, cold and with artificial lighting; the constant inter-relation between the same team members during the shift and conflicting decision making related to which patients will be attended to are appointed as factors that trigger anxiety and mental disorders in nursing workers at these units, including depression ${ }^{(3-4)}$. Depression is characterized by a generally depressive mood, sadness, loss of interest or pleasure, significant weight loss or gain, insomnia (in the initial, middle or end sleep phases) or hypersomnia, agitation or psychomotor delay, fatigue or energy loss, feeling of uselessness or excessive or inadequate guilt, indecision or decreased ability to think or concentrate and recurrent death thoughts.

In combination with these stressful factors nursing workers experience at Intensive Care Units, another factor researchers appoint as a trigger of mental disorders in this population is the occurrence of nursing professionals' shift turnovers, which can cause sleep alterations, gastrointestinal and cardiovascular disorders and mental disorders, mainly depression ${ }^{(5)}$. Likewise, besides entailing difficulties to sleep and wake up, night work can make workers abuse of alcohol or barbiturates, causing irritation and aggressiveness and, thus, harming their family and social life(6).

Researchers $^{(7)}$ have appointed that little has been reported on the prevalence of depression symptoms among nursing workers, which is verified when analyzing Brazilian and international production on the theme. In literature, studies address aspects like: anxiety, stress and Burnout Syndrome in a wide range of activity areas. Various authors have researched on this theme, but not as the central focus in depression research ${ }^{(7-10)}$.

These facts demonstrate the need for studies to assess that type of problem in the nursing population.

In the few studies that mention depression among ICU nursing workers, researchers unanimously affirm that exposure to a range of stressful events at the Intensive Care Unit may be associated with increased prevalence of depression in nursing workers at these units $^{(8)}$. Studies have evidenced that ICU nurses, mainly those working at general ICUs, have shown a trend towards depression ${ }^{(8)}$. A study aiming to identify the Burnout Syndrome in Intensive Care Unit nurses evidenced high prevalence rates of depressive symptoms in that population, suggesting that qualitative analyses of depressive symptoms in ICU nurses should be better investigated $^{(9)}$. In a study involving 130 nursing workers from a general hospital, it was found that $27 \%$ of this sample complied with criteria for depression(5). In Brazil, few studies have been published on the theme. Among the few available publications, one study aimed to assess the quality of life and prevalence of dysphoria/ depression among nursing residents from a university hospital in the interior of São Paulo State. This study evidenced the prevalence of dysphoria/depression in $27.9 \%$ of the residents ${ }^{(7)}$.

Another study accomplished to assess quality of life at work, which involved 211 surgical center nursing workers, evidenced that $24.2 \%$ of the interviewed workers evidences depression symptoms ${ }^{(9)}$. 
In view of the fact that depression has been documented in health professional working in various specialties, that the ICU nursing team constitutes a vulnerable group for the development of depression, due to the situations that reveal the great emotional burden these professional are exposed to and considering that little is known about depression in nursing workers at these units, besides the lack of studies that investigated the presence of depression alone in Brazilian nursing workers, this study aims to verify the prevalence of depression in Intensive Care Unit workers.

\section{Aim}

To verify the prevalence of depression in nursing workers from Intensive Care Units in hospitals from a Northwestern city in São Paulo State, analyzing its association with participants' socio-demographic characteristics.

\section{Methods}

Data for this cross-sectional study were collected at three hospital institutions from a Northwestern city in São Paulo State. One of the study hospitals was classified as medium-sized and private, called hospital A in this paper, while the other two were large philanthropic hospitals and called hospitals B and C. The study subjects were 67 nursing workers from three categories: nurses, nursing technicians and auxiliaries, working at the Intensive Care Units of each of the three institutions involved. The following inclusion criteria were established: being an ICU worker, working at the time of data collection and accepting to participate in the study.

\section{Ethical considerations}

The following ethical aspects were observed in the accomplishment of this research: approval of the project by the Institutional Review Board of Faculdades Integradas Fafibe, under Number 0051/2006, and the study participants' signing of the Informed Consent Term.

\section{Measurement instruments}

To collect data on depression, Beck's Depression Inventory (BDI) was used. This depression selfassessment scale was introduced at the Center for Cognitive Therapy - CCT of Pennsylvania University Medical School in $1971^{(11)}$. The BDI has been widely used to assess cognitions associated with depression in psychiatric patients and in normal populations. It is one of the most accepted instruments to assess the intensity of depression and displays one of the best performance levels in this function ${ }^{(11)}$. Besides, the BDI has demonstrated its reliability, independently of culture, socioeconomic level, education, age, marital status and partner's occupation. In 1998, the BDI was validated in Brazil(12).

Although it is a depression intensity measure, the tool is not indicated to recognize nosological categories. The BDI comprises 21 items, including symptoms and attitudes, each of which consists of four assertions with intensity levels graduated from 0 (neutral) to 3 (maximum intensity), and a score range from 0 to 63. BDI items refer to sadness, pessimism, feeling of failure, lack of satisfaction, feeling of guilt, feeling of punishment, self-accusations, suicidal ideas, crying crises, irritability, social retraction, indecision, distorted body image, inhibition to work, sleep disorder, fatigue, loss of appetite, weight loss, somatic concern and decreased libido. The cut-off score depends on the sample type and study aims.

Different cut-off points have been proposed to use the BDI, depending on the type of sample and aims of the study. In the BDI's original psychometric properties, the obtained results should be interpreted as follows: $>10=$ no depression or minimum depression from 10 to $18=$ mild to moderate depression; from 19 to 29=moderate to severe depression; from 30 to $63=$ severe depression $^{(11)}$. In non-diagnosed samples, however, that is, which have not been medically diagnosed with depression, like the participants in this study, literature recommends that the following measures be adopted: $\leq 15=$ normal or mild depression; 16-20=dysphoria; >20=Depression(12). Together with the BDI, a questionnaire was also applied to identify the participants socio-demographic profile, comprising 14 questions related to gender, age, marital status, work shift, time on the job, among others.

\section{Procedures}

Data collection instruments were distributed at the subjects' places of work, during the three shifts (morning, afternoon and night). After they accepted, they were asked to sign the Informed Consent Term and not identify the questionnaires, so as to preserve their identity. After they received the tools, a 48 hour-interval was established for the subjects to return the completed instruments.

Data analysis was divided in two moments; initially, data were subject to descriptive statistical analysis. 
Participants were classified according to BDI results in two groups: group I with depression (individuals scoring $>20$ ) and group II without depression (individuals scoring $\leq 20$ ). After dividing the groups, univariate logistic regression was applied to identify which variables significantly influences the workers' depression, in the form of measures to estimate the Odds Ratio (OR), with a $95 \%$ confidence interval. All variables with $p \leq 0.20$, (gender, age, marital status, work shift, time on the job, time working at ICU, being a student) were introduced in the multiple logistic regression model stepwise. Statistics with a descriptive $\mathrm{p} \leq 0.05$ were considered significant. All analyses were carried out in SPSS version 13.0 for Windows.

\section{Results}

\section{Sample characteristics}

In the population of 85 workers who were invited to participate in the study, $79 \%$ returned the completed instrument, while $21 \%$ did not. Thus, the study sample consisted of 67 participants, the majority of whom (55\%) were female, with ages ranging between 21 and 30 years $($ mean $=25$ years; $S D=3.87$ ), $51 \%$ were single, $66 \%$ worked as nursing technicians and $58 \%$ informed they had more than one job. As for the work shift, most participants (40\%) worked in the afternoon, 39\% had been working at the Intensive Care Unit between one and five years. Regarding sample origin, 17 (25\%) participants came from the ICU at Hospital A, 18 (27\%) from the ICU at Hospital B and 32 (48\%) from the ICU at Hospital C.

\section{Depression prevalence according to the adopted BDI}

According to the cut-off points established in data analysis, it was observed that $70 \%$ of the interviewees were classified as no depression or mild depression; $21 \%$ with dysphoria (moderate depression) and $9 \%$ with depression (severe depression), as shown in Picture 1.

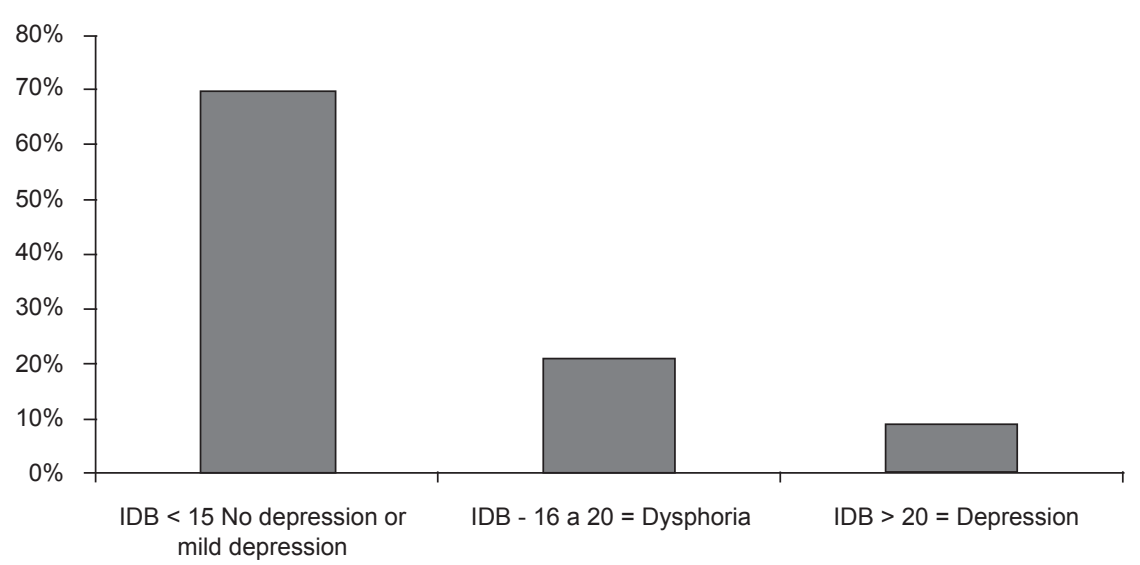

Figure 1 - Distribution of study participants according to depression prevalence, in line with the Beck Depression Inventory. São Paulo, SP, Brazil, 2010

To proceed with the statistical analyses, the participants were grouped according to their BDI results, in two groups: I with depression and II without depression. It was observed that, after this classification, $47(71.6 \%)$ participants were considered without depression, while 20 (28.4\%) obtained scores that suggested depression.

Applying univariate logistic regression, the association between the study variables showed no significance between depression and the following: gender, age, professional category, time on the job, time working at the ICU, graduate degree and being a student. Therefore, they were not incorporated into the multiple logistic regression models. In the latter, those variables were included that had demonstrated statistical significance in the univariate analysis, which were: marital status, work shift, number of jobs, which showed a positive association with depression prevalence among nursing workers. In the analysis according to the multiple model, the significant association between these variables and depression continued. The main predictor of this association was observed in participants working double shifts ( $O R=2.11$ ), followed by separated and/ or divorced individuals $(O R=1.56)$ working night shifts $(\mathrm{OR}=1.48)$ (Table 1$)$. 
Table 1 - Logistic regression result analysis, considering the relation between depression and significant study variables. São Paulo, Brazil, 2010

\begin{tabular}{lccc}
\hline \multicolumn{1}{c}{ Variables } & OR & $\mathbf{9 5 \%} \mathbf{C l}$ & $\mathbf{P}$ \\
\hline $\begin{array}{l}\text { Marital status } \\
\text { Single }\end{array}$ & 1.00 & & \\
$\quad \begin{array}{l}\text { Married/fixed partner } \\
\text { Separated/divorced }\end{array}$ & 0.367 & $(0.42-1.70)$ & 0.282 \\
Work shift & 1.568 & $(1.32-1.84)$ & 0.035 \\
$\quad$ & & & \\
$\quad$ Nay & 1.00 & & 0.000 \\
$\quad$ Night & 1.459 & $(1.42-1.78)$ & 0.028 \\
$\quad$ Single journey & & & \\
$\quad$ Double journey & 1.00 & & 0.000 \\
\hline
\end{tabular}

The analysis of participants' answers to the 21 items in the Beck Depression Inventory showed that, as to the feeling of pleasure, $40 \%$ of participants informed no longer feeling pleasure like before; $46.3 \%$ mentioned feeling guilty sometimes. As for deception, $52 \%$ of the interviewees indicated feeling that their weaknesses and errors had worsened and that they felt more guilty for their failures; $30 \%$ informed that they tend to cry more than the usual; on the item addressing irritation, $40 \%$ of the subjects said they were irritated all the time; $43 \%$ said they do not sleep as well as they used to and $50 \%$ get tired more easily than they used to. Regarding libido, $30 \%$ of the participants informed they were not interested in sex like before.

\section{Discussion}

The ICU environment is characterized as highly stressful and exhausting and can be associated with high depression rates among ICU workers. Based on this evidence, the $\mathrm{BDI}^{(11)}$ was applied, a self-assessment instrument that has been widely acknowledged in different countries and assesses the prevalence and intensity of depression. It can be used in psychiatric patients as well as in the non-clinical population. Its predictive value corresponds to approximately $90 \%{ }^{(13-14)}$. The depression prevalence found in this study was $28.4 \%$. This result was consistent with international research(8) results, which found a $27 \%$ depression prevalence among nursing workers and slightly higher when compared with the results of a Brazilian study ${ }^{(7)}$, in which the prevalence of depression amounted to $27.9 \%$.

In the total sample, according to BDI scores, $71.6 \%$ of the interviewees were classified as no depression or minimum depression; $20 \%$ as dysphoria or mild/ moderate depression and $8.4 \%$ showed sufficient scores for depression or severe depression. In view of these results, it needs to be considered that the BDI is not a diagnostic instrument and that depression cannot be diagnosed based on its results only, demanding concomitant clinical assessment. The results suggested that more than a quarter of the sample complies with criteria for depression and that, among these, $8 \%$ present severe depression. Data are a source of concern as, although this situation was detected, workers are still exposed to stressful and anguishing factors at the ICU. Ignoring the anguish and depression signs these professionals present results in low-quality care and work burden, including emotional and physical stress ${ }^{(15)}$.

It is highlighted that, as $21 \%$ of the 85 workers who were invited to participate in the study did not return the questionnaire, it can be inferred, as one hypothesis for this non-return percentage, that they were afraid to reveal their symptoms and be identified by the service, although it was informed at the time of data collection that the provided data would be kept secret. Thus, these workers' participation could have interfered in the results, entailing higher depression prevalence rates as, when the data were collected, many workers were on a leave of absence as a result of a depression diagnosis.

Regarding depression prevalence in nursing workers, according to each of the three ICUs under analysis, no significant difference in depression prevalence and percentages was found, ranging from $29 \%$ at the ICU in Hospital A to $18 \%$ at the ICU in Hospital B and $23 \%$ in Hospital $\mathrm{C}$. The fact that higher depression prevalence rates were find at the ICU of the private hospital may be due to the greater pressure exerted at these institutions, which can enhance the exhausting characteristics of ICUs, contributing as an additional factor to trigger depression in workers.

The study found a statistical association between the presence of depression and working double shifts (Table 1). Nursing workers need to work double shifts due to the economic situation in the health area, with low wages in most cases, which are insufficient for family maintenance and make professionals seek new income sources. In fact, they need to face double activities, which can interfere in some aspects of workers' quality of life, entailing psychic symptoms, among others ${ }^{(16)}$. The effect of double journeys on nursing workers' mental health was found in a study aimed at verifying stress prevalence in two groups of workers. The results evidenced that $70.8 \%$ of the group working double journeys was stressed, in comparison with $55.5 \%$ in the group without double journeys(16). 
At bottom, double work journeys can be associated with depression in nursing workers due to the deprivation of leisure and social contact, needed to maintain their mental health.

Another predictive factor of depression among participants in this study was night work. Shift work is a characteristic of nursing practice and obligator, as nursing care happens 24 hours per day, seven days per week, without interruptions. This condition obliges care delivery at night, at weekends and during holidays, when other workers sleep, relax, involve in leisure and social and family contact.

These aspects contribute to the appearance of depression in workers who perform their activities at night. This result was consistent with other studies ${ }^{(16-}$ 18), appointing that nursing workers more strongly feel the psychosocial factors of shift work, which interfere in health and disease processes ${ }^{(19-20)}$. Night work is harmful to occupational health, due to the critical, exhausting and tiresome work conditions, associated with the already exhausting characteristics of the ICU environment, enhancing its effects on nursing workers' mental health. A study that assessed the sleep quality of ICU nursing workers found that $100 \%$ of the nurses and $88 \%$ of the nursing auxiliaries assessed showed bad sleep quality, which seems to justify experts' observations on the topic, in that night workers' main challenge is undoubtedly to adapt their life rhythm to biological principles and social contact $^{(21)}$, considering that the combination between discouragement and fatigue makes the interest in social life and leisure disappear.

Besides causing an intense form of irritability in voices and domestic noise, due to constant and/or disturbing sounds, like in the ICU environment ${ }^{(17)}$. Thus, constant discouragement due to night work and the lack of social and family contact imposed by the exhaustion related to night work can lead to manifestations of depression in workers.

Besides double journeys and night work, another variable that demonstrated a significant association with depression in ICU nursing workers was marital status. In this study, the association between depression prevalence and marital status was significant; divorced or separated workers showed greater chances of depression than single or married ones, in line with the results observed in a similar study(22). In view of this result, one may say that the support in family relations and marriages is inversely related with the development of stress and physical illnesses(23) and depression and that, in individuals without this type of support, occupational stress rates increase ${ }^{(24)}$. This observation corroborates the evidence that married nurses experience less occupational depression thanks to family support(25).

Despite the lack of isolated scores in depression assessment according to the BDI, it was considered important to discuss the results observed on some instrument items, which evidenced a higher prevalence rate than for depression itself. Significant percentages of ICU professionals informed feeling sad, discouraged about the future, no longer feeling pleasure in things like before; feeling guilty, getting easily irritated and presenting sleep problems, although depression prevalence corresponded to $28.4 \%$. These results can indicate psychic suffering. When not observed and adequately managed, they can trigger depression. According to literature ${ }^{(2)}$, the most typical characteristics of depressive people are feelings of sadness or void, complaints about losing pleasure in doing activities in general, and decreased interest in the environment associated with the feeling of fatigue and/or tiredness.

This study presented various limitations. First, the number of study participants, which did not permit generalizing the results and may have influenced the results observed, as no significant difference was found between most research variables, which may be attributed to the low power of the sample involved. Anyway, the results found were similar to those of previous studies of the same kind. Second, the fact that, when used alone, the instrument has no diagnostic power and, thus, with a view to greater reliability of the results, workers whose score suggested depression should e submitted to clinical assessment with a view to confirming depression.

Despite the limitations, the study offers advantages for nursing knowledge, to the extent that it contributes to Brazilian literature on the theme, mainly in view of the observation that, until date, no studies published in Brazil are available which studied depression in ICU nursing workers as, despite some studies on these workers' mental health, none of them adopted depression as the main research focus.

\section{Conclusion}

Prevalence levels of depression in nursing workers at the ICUs under analysis amount to almost $30 \%$. Working night shifts, working double shifts and being separated or divorced are characteristics positively associated with depression in this population. Hospital institutions need to get more concerned with these workers' physical and mental health, as the percentages of workers who informed discouragement, sadness and despair were significantly high. These can be precursor 
symptoms of more severe depression among workers as, at bottom, these factors may negatively influence nursing care delivery in the ICU context.

Finally, other studies of this kind should be accomplished to obtain further knowledge on the theme, which can and should support strategies aimed at guaranteeing quality of life at work to ICU nursing workers. This presupposes, among other factors, heeding the presence of depression among these workers.

\section{References}

1. Missel ST. A Saúde geral de profissionais da área hospitalar: uma avaliação comparativa entre grupos com contato direto e indireto compacientes [dissertação de mestrado]. Canoas (RS): Universidade Luterana do Brasil; 1998. 100 p.

2. Porto JAD. Conceito e diagnóstico. Rev Psiq Clin. 1999;21(1):1-13.

3. Villa VSC, Rossi L. O Significado Cultural do Cuidado Humanizado em Unidade de Terapia Intensiva: Muito falado e pouco vivido. Rev. Latino-Am. Enfermagem. 2002;10(2):137-44.

4. Leite MA, Villa VSC. Dificuldades vivenciadas pela equipe multiprofissional na unidade de terapia intensiva. Rev. Latino-Am. Enfermagem. 2005;13(2):145-50.

5. Costa ES, Morita I, Martinez MAR. Percepção dos efeitos do trabalho em turnos sobre a saúde e a vida social em funcionários da enfermagem em um hospital universitário do estado de São Paulo. Cad Saúde Pública. 2000;16(2):553-5.

6. Carvalho GM. Enfermagem do Trabalho. São Paulo: EPU; 2001.

7. Franco GP, Barros ALBL, Nogueira-Martins LA. Qualidade de vida e sintomas depressivos em residentes de enfermagem. Rev. Latino-Am. Enfermagem. 2005;13(2):139-44.

8. Özgencil E, Ünal N, Oral M, Okyavuz Ü, Alanoglu Z. Depression and burnout syndrome in intensive care unit nurses. J Int Women's Study. 2004;8(Suppl 1):340.

9.Schmidt DRC. Qualidade de vida no trabalho e sua associação com o estresse ocupacional, a saúde física e mental e o senso de coerência entre profissionais de enfermagem do Bloco Cirúrgico [tese de doutorado]. Ribeirão Preto (SP): Escola de Enfermagem de Ribeirão Preto da Universidade de São Paulo; 2009. 243 p.

10 Poncet MC, Toullic P, Papazian L, Kentish-Barnes N, Timsit J-F, Pochard F, et al. Burnout Syndrome in Critical Care Nursing Staff 2001. Am J Respir Crit Care Med. 2007;175:698-704.

11. Silveira DS, Jorge MR. Propriedades psicométricas da escala de rastreamento populacional para depressão
CES-D em populações clínica e não-clínica de adolescentes e adultos jovens. Rev Psiq Clin. 1998;25(5):251-61.

12. Gorenstein C, Andrade L. Inventário de Beck: Propriedades Psicométricas da Versão em Português. Rev Psiq Clin. 1998;25(5):245-50.

13. Donchin Y, Seagull FJ. The hostile environment of the intensive care unit. Curr Opin Crit Care. 2002;8:316-20.

14. Soupios MA, Lawry K. Stress on personnel working in a critical care unit. Psychiatr Med. 1987;5:187-98.

15. Andrade C. Cuidados Intensivos. Rio de Janeiro: McGraw-Hill; 2002. 436 p.

16. Pafaro RC, Martino MMF. Estudo do estresse do enfermeiro com dupla jornada de trabalho em um hospital de oncologia pediátrica de Campinas. Rev Esc Enferm USP. 2004; 38(2):152-60.

17. Barboza JIRA, Moraes EL, Pereira EA, Reimão RNAA. Avaliação do padrão de sono dos profissionais de Enfermagem dos plantões noturnos em Unidades de Terapia Intensiva. Einstein. 2008; 6(3):296-301.

18. Abdalkader RH, Hayajneh FA. Effect of Night Shift on Nurses Working in Intensive Care Units at Jordan University Hospital. Eur J Sci Res. 2008;23(1):70-86.

19. Moreno CRC, Fischer FM, Rotenberg L. A saúde do trabalhador na sociedade 24 horas. São Paulo Perspec. 2003;17(1):34-46.

20. Fischer MF, Teixeira LR, Borges FNS, Gonçalves MBL, Ferreira RM. Percepção de sono: duração, qualidade e alerta em profissionais da área de enfermagem. Cad Saúde Pública. 2002;18(5):1261-9.

21. Rotenberg L, Portela LF, Marcondes WB, Moreno C, Nascimento CP. Gênero e trabalho noturno: sono, cotidiano e vivências de quem troca a noite pelo dia. Cad Saúde Publica. 2001;17(3):639-49.

22. Habibollah Kavari, Mahnaz Helyani, Vida Dehghani. A Study of Depression Prevalence in Nurses and it's Effective Factors in Shiraz Namazi Hospital. Rawal Med J. 2007;32(2):184-6. 23. Norbeck JS. Types and sources of social support for managing Job stress in critical care nursing. Nurs Res. 2001;34(4):223-5.

24. McAbee R. Occupational stress and burnout in the nursing progression, a mode of prevention. AAOHN J. 1991;39(12):568-85.

25. Morano J. The relationship of workplace social support to perceived work-related stress a many staff nurses. J Post Anesth Nurs. 2000;8(6):395-402. 